\title{
The Unvarnished Truth
}





\title{
The Unvarnished Truth
}

\author{
Personal Narratives \\ in Nineteenth-Century America
}

\author{
Ann Fabian
}

UNIVERSITY OF CALIFORNIA PRESS

Berkeley Los Angeles London 
University of California Press

Berkeley and Los Angeles, California

University of California Press, Led.

London, England

First paperback printing 2001

(C) 2000 by the Regents of the University of California

Library of Congress Cataloging-in-Publication Data

Fabian, Ann.

The unvarnished truth: personal narratives in nineteenth-century America / Ann Fabian. p. cm.

Includes bibliographical references and index.

ISBN 978-0-520-23201-3 (pbk. : alk. paper).

1. United States-History-19th century-Biography. 2. Autobiography. 3. Poor-United States-Biography. I. Title.

$\mathrm{E}_{337.5 . F 33 ~} 2000$

$920.073-\mathrm{dc} 21$

$99-12652$

CIP

Manufactured in the United States of America

$10 \quad 0908$

$\begin{array}{lllllllll}10 & 9 & 8 & 7 & 6 & 5 & 4 & 3 & 2\end{array}$

The paper used in this publication is both acid-free and totally chlorine-free (TCF). It meets the minimum requirements of ANSI/NISO Z39.48-1992 (R 1997) (Permanence of Paper). () 
For my mother, Virginia Fabian 
In democracies it is by no means the case that all the men who cultivate literature have received a literary education; and most of those who have some tinge of belles-lettres are either engaged in politics, or in a profession which allows them to taste occasionally and by stealth the pleasures of the mind.... They prefer books which may be easily procured, quickly read, and which require no learned researches to be understood.

$$
\begin{array}{r}
\text { Alexis de Tocqueville, "Literary Characteristics } \\
\text { of Democratic Ages," Democracy in America (1840) }
\end{array}
$$

In democratic communities each citizen is habitually engaged in the contemplation of a very puny object, namely himself. If he ever raises his looks higher, he then perceives nothing but the immense form of society at large, or the still more imposing aspect of mankind. His ideas are all either extremely minute and clear, or extremely vague: what lies between is an open void.

Alexis de Tocqueville, "Of the Inflated Style of American Writers and Orators," Democracy in America (1840) 